\title{
High-temperature chalcocite in silicate slag melt and implications for mineralogy of sulfides from natural $\mathrm{Cu}$-rich exotic melts
}

\author{
KATARZYNA A. DERKOWSKA ${ }^{1,2}$ AND JAKUB \\ CIĄŻELA ${ }^{3}$ \\ ${ }^{1}$ University of Wroclaw \\ ${ }^{2}$ Polish Geological Institute - National Research Institute \\ ${ }^{3}$ Institute of Geological Sciences, Polish Academy of Sciences, \\ Research Centre in Wrocław \\ Presenting Author: katarzyna.derkowska@uwr.edu.pl
}

Chalcocite is a common $\mathrm{Cu}$ ore mineral in outer zones of magmatic-hydrothermal porphyry $\mathrm{Cu}$ deposits and sedimenthosted $\mathrm{Cu}$ deposits. However, the occurrence of chalcocite in magmatic base sulfides is unknown or highly limited. Interestingly, we have observed chalcocite-containing sulfides in cooled silicate slag melts. Sulfides textures, chemical composition, as well as temperature and oxygen fugacity conditions, strongly resemble those known from the lower crust mafic environment.

The analyzed pyrometallurgical slags are a product of historical $\mathrm{Cu}$ smelting from Polish strata-bound type $\mathrm{Cu}$ ores, related to the marginal, oxidized part of the Zechstein Kupferschiefer formation in the North-Sudetic Basin, Poland. Slags are composed of $\mathrm{SiO}_{2}$ (42-50 wt \%), $\mathrm{CaO}(17-27 \mathrm{wt} \%)$ and $\mathrm{Al}_{2} \mathrm{O}_{3}(17 \mathrm{wt} \%)$ with variable amounts of $\mathrm{Fe}_{2} \mathrm{O}_{3}(2-20 \mathrm{wt} \%)$ and high $\mathrm{K}_{2} \mathrm{O}$ contents (4-7 wt\%). The slag material represents remelted and re-crystallized gaunge, mixed with unextracted ore, which results in exceptionally high $\mathrm{Cu}$ content of this melt ( $\sim 4.4$ wt $\% \mathrm{Cu}$ ). Copper is held by metallic $\mathrm{Cu}$ (an anthropogenic analogue of native $\mathrm{Cu}$ ), copper-iron sulfides (chalcopyrite, bornite), and chalcocite. The thermodynamic reconstructions with MELTs software [1] showed that the liquidus temperature of $\sim 1200^{\circ} \mathrm{C}$ was exceeded. Thus, observed sulfides are not unmelted remains of the original ore.

Although magmatic base sulfides are usually associated with ultramafic and mafic systems, deposits of exotic $\mathrm{Cu}$-rich compositions in alkaline environments are also known [2]. The composition of the analyzed materials is not far from mafic magmas but is featured by low $\mathrm{MgO}$, as well as high $\mathrm{K}_{2} \mathrm{O}$ and $\mathrm{Cu}$ contents. We believe that either a particular melt chemical composition or distinct pressure conditions $(0.1 \mathrm{MPa}$ on the surface compared to 200-500 MPa in typical mafic melts) are the reasons for high-temperature chalcocite crystallization.

The study was funded by Polish National Science Centre to KD (project UMO-2019/35/N/ST10/04524).

References:

[1] Kadziolka, Pietranik, Kierczak, Potysz \& Stolarczyk (2020), Journal of Archaeological Science 118, 105142.

[2] Graham, Holwell, McDonald, Jenkin, Hill, Boyce, Smith \& Sangster (2017), Ore Geology Reviews 80, 961-984. 